\title{
The Eco-Efficiency Premium Puzzle
}

Citation for published version (APA):

Derwall, J. M. M., Günster, N. K., Bauer, R. M. M. J., \& Koedijk, C. G. (2005). The Eco-Efficiency Premium Puzzle. Financial Analysts Journal, 61(2), 51-63. https://doi.org/10.2469/faj.v61.n2.2716

Document status and date:

Published: 01/01/2005

DOI:

10.2469/faj.v61.n2.2716

Document Version:

Publisher's PDF, also known as Version of record

\section{Please check the document version of this publication:}

- A submitted manuscript is the version of the article upon submission and before peer-review. There can be important differences between the submitted version and the official published version of record.

People interested in the research are advised to contact the author for the final version of the publication, or visit the DOI to the publisher's website.

- The final author version and the galley proof are versions of the publication after peer review.

- The final published version features the final layout of the paper including the volume, issue and page numbers.

Link to publication

\footnotetext{
General rights rights.

- You may freely distribute the URL identifying the publication in the public portal. please follow below link for the End User Agreement:

www.umlib.nl/taverne-license

Take down policy

If you believe that this document breaches copyright please contact us at:

repository@maastrichtuniversity.nl

providing details and we will investigate your claim.
}

Copyright and moral rights for the publications made accessible in the public portal are retained by the authors and/or other copyright owners and it is a condition of accessing publications that users recognise and abide by the legal requirements associated with these

- Users may download and print one copy of any publication from the public portal for the purpose of private study or research.

- You may not further distribute the material or use it for any profit-making activity or commercial gain

If the publication is distributed under the terms of Article $25 \mathrm{fa}$ of the Dutch Copyright Act, indicated by the "Taverne" license above, 


\title{
The Eco-Efficiency Premium Puzzle
}

\author{
Jeroen Derwall, Nadja Guenster, Rob Bauer, and Kees Koedijk
}

\begin{abstract}
Does socially responsible investing (SRI) lead to inferior or superior portfolio performance? This study focused on the concept of "eco-efficiency," which can be thought of as the economic value a company creates relative to the waste it generates, and found that SRI produced superior performance. Based on Innovest Strategic Value Advisors' corporate eco-efficiency scores, the study constructed and evaluated two equity portfolios that differed in eco-efficiency. The high-ranked portfolio provided substantially higher average returns than its low-ranked counterpart over the 1995-2003 period. This performance differential could not be explained by differences in market sensitivity, investment style, or industry-specific factors. Moreover, the results remained significant for all levels of transaction costs, suggesting that the incremental benefits of SRI can be substantial.
\end{abstract}

$\mathbf{I}$ $\mathrm{n}$ recent decades, a large number of investors have embraced the concept of socially responsible investing (SRI). Currently, nearly 12 percent of assets under management are invested according to ethical criteria (Social Investment Forum 2001). However, despite the increasing popularity of SRI, debate continues over whether adding an ethical dimension to the stock selection process adds value.

Many businesspeople believe that companies cannot use their financial resources to improve social or environmental performance without decreasing shareholder value. A common line of reasoning is that a company's costs of adhering to ethical standards will translate into higher product prices, a competitive disadvantage, and lower profitability (Walley and Whitehead 1994).

Others believe that improved social or environmental performance can enhance a company's input-output efficiency or generate new market opportunities. Porter and Van der Linde (1995) argued that active policies to improve environmental performance can create a competitive advantage because of the more cost-efficient use of resources. If this argument is true and the benefits of social or environmental initiatives outweigh their costs, then businesses that embrace the concept of corporate

Jeroen Derwall is a research associate at the RSM Erasmus University, Rotterdam, the Netherlands. Nadja Guenster is a research associate at the RSM Erasmus University, Rotterdam, the Netherlands. Rob Bauer is research department head at $A B P$ Investments and a professor of finance at Maastricht University, the Netherlands. Kees Koedijk is a professor of financial management at RSM Erasmus University, Rotterdam, the Netherlands, and a research fellow at the Centre for Economic Policy Research. environmental responsibility should be able to report higher corporate earnings than less responsible companies.

The extent to which social or environmental screening policies contribute to investment returns, however, depends on the financial markets' ability to factor the financial consequences of corporate social responsibility into share prices. The belief is widespread that at the investment level, incorporating ethical criteria into investment decisions comes at the cost of portfolio performance. Asset-pricing theory that relies on the efficient market hypothesis posits that (1) investment portfolios deliver returns proportional to associated risk and that (2) the optimal investment portfolio is a well-diversified one. Therefore, any empirical evidence of anomalous risk-adjusted investment performance on the part of stocks grouped by company-specific characteristics-such as size, book-to-market ratio (BV/MV), or corporate social responsibility-are attributable to deficiencies in the performance evaluation models that attempt to explain them. After the methodological shortcomings are corrected, no abnormal returns should exist.

This reasoning suggests that socially responsible investors, who would be inherently suffering from imposed limits to diversification, should report suboptimal returns when the appropriate performance attribution framework is used. Proponents of SRI, however, typically argue that corporate social responsibility reflects the company managers' views on how the company will perform in the long term. These views may be mispriced because of short-term thinking within the financial community. This school of thought suggests that SRI can be incrementally profitable over long-run horizons. 
The central empirical question arising from this debate is whether corporate social or environmental responsibility is associated with financial performance. A large body of literature has investigated the social-financial performance link empirically by comparing the historical returns of socially responsible mutual funds with those of conventional funds or market indexes. ${ }^{1}$ Although this approach provides useful evidence on the financial consequences of SRI in a practical context, the method has some limitations. Results from mutual fund studies may be biased because of nonquantifiable aspects, such as management skill, unknown portfolio holdings, and screening methods. Furthermore, mutual fund studies cannot establish whether a social or environmental responsibility premium exists because holdings of social funds and conventional funds are not mutually exclusive.

In this study, we avoided these difficulties by using the Innovest Strategic Value Advisors rating database to evaluate self-composed equity portfolios. (Despite being well established in the investment community, these ratings are rarely used in empirical research.) The Innovest scores build on the concept of "eco-efficiency," which can be interpreted as the economic value a company adds (e.g., by producing products and delivering services) relative to the waste it generates when creating that value.

Focusing exclusively on the environmental element of social responsibility, our study investigated whether a long-run premium or penalty exists for holding environmentally responsible companies. We constructed two mutually exclusive portfolios with distinctive eco-efficiency scores. We then applied performance attribution models to test whether any performance differential between the portfolios was significant and attributable to the environmental component. This method allowed us to examine the long-term benefits of including environmental criteria in the investment process.

We explicitly attempted to overcome the performance attribution problems outlined earlier by using several sophisticated performance evaluation methods. Following Carhart (1997), we evaluated the portfolios while controlling for multiple nonenvironmental factors known to determine stock performance. This process is a methodological improvement on most related studies, which typically account only for volatility or market risk. The major benefit of the approach we used, as empirically confirmed by Fama and French (1993) and Carhart, is that we also controlled for the presence of style tilts (based on, for example, size, value versus growth, or momentum effects) in stock portfolios. This approach is particularly important because of the mounting evidence that environmentally and socially screened portfolios in the United States tend to be biased toward largecapitalization growth stocks (see, for example, Bauer, Koedijk, and Otten, forthcoming 2005). Following Geczy, Stambaugh, and Levin (2003), our study applied a four-factor model augmented by factors that capture industry effects in socially responsible equity portfolios.

\section{Environmental Responsibility and Stock Returns}

A large body of literature has investigated the relationship between environmental and financial performance. Unfortunately, the empirical evidence to date is inconsistent. As pointed out by Ullman (1985) and by Griffin and Mahon (1997), the conflicting results in prior research are mainly attributable to differences in methodology and in the choice of financial and environmental performance indicators. For the studies that used stock returns as the financial performance measure, Wagner (2001) identified three categories: portfolio studies, event studies, and (multivariate) regression studies.

Portfolio studies typically compose mutually exclusive portfolios based on various corporate social performance indicators and investigate the portfolios' return differences over some investment horizon. For instance, Diltz (1995) studied daily returns for a variety of portfolios constructed on the basis of several ethical performance indicators. Diltz found that, although many screens did not improve portfolio performance significantly, environmental screens enhanced stock performance significantly during the 1989-91 period. Cohen, Fenn, and Konar (1997) constructed industry-balanced portfolios with different environmental responsibility characteristics to investigate the financial performance difference between low-polluter and high-polluter companies in the United States. Contrary to the Diltz study, their findings suggest that there is neither a premium nor a penalty for investing in companies that are leaders in nonpollution issues. A comparison by Yamashita, Sen, and Roberts (1999) of 10-year risk-adjusted returns showed, however, that their environmentally highest-ranked stocks performed significantly better than the lowest-ranked stocks. White (1996), furthermore, examined the performance of "green," "oatmeal," and "brown" equity portfolios and demonstrated that the green portfolio provided a significantly positive Jensen's alpha while the other two alternatives failed to outperform the market. In addition to these studies, some studies have compared self-composed socially screened 
portfolios with a regular investment portfolio. One of Innovest's online research publications (Blank and Daniel 2002) discussed the potential usefulness of eco-efficiency scores in making investment decisions. Blank and Daniel reported that an equalweighted eco-efficiency portfolio delivered somewhat higher Sharpe ratios than the S\&P 500 Index during the 1997-2001 period. Finally, Guerard (1997) used the social performance database of Kinder, Lydenberg, Domini \& Company and concluded that portfolios derived from a socially screened investment universe did not perform differently from those obtained from an unscreened set during the 1987-96 period.

The most pronounced evidence of a link between environmental and stock market performance is found in event studies. Shane and Spicer (1983) documented that companies experienced abnormal declines in stock prices two days prior to their pollution figures being reported by the Council on Economic Priorities in the United States. Moreover, on the day of publication, negative returns were significantly larger for companies with relatively poor records of pollution control than for companies with better rankings. Hamilton (1995) reported a significantly negative abnormal return for publicly traded companies following the first release of their TRI (toxics release inventory) pollution figures. Consistent with previous results, Klassen and McLaughlin (1996) found evidence that positive corporate events, measured by environmental awards given to companies by third parties, are associated with positive subsequent abnormal returns. Significantly negative returns tend to follow environmental crises. Similarly, Rao (1996) reported that the performances of companies following pollution reports by the Wall Street Journal between 1989 and 1993 were significantly below the companies' expected market-adjusted returns. Only Yamashita et al., studying scores of environmental conscientiousness published in July 1993's Fortune magazine, did not find significant stock market responses to the scores.

A third category of literature has used primarily regression or correlation analysis to examine whether a long-term relationship exists between corporate environmental responsibility and stock performance. Taken as a whole, these studies provide only limited support for such a relationship. Spicer (1978) documented that companies in the U.S. pulp and paper industry with the better pollution control records have higher profitability and lower stock betas. Chen and Metcalf (1980), however, in replicating Spicer's study but controlling for the impact of company size on environmental performance, cast doubt on his findings. Using a similar method, Mahapatra (1984) also found no evidence that pollution control initiatives are rewarded with improved stock performance.

Most prior research, implicitly resting on Sharpe's (1964) CAPM (capital asset pricing model) framework, controlled portfolio performance or observed relationships for only a single risk factor. Evidence presented by Fama and French and by Carhart indicates, however, that a single factor cannot explain the cross-sectional variation in equity returns. Therefore, the relationship between environmental and financial performance observed in studies to date may have been driven by latent factors that were not used as control variables in the research. Surprisingly, the empirical literature addressing some of such unobserved influences is limited to non-U.S. studies. They include Thomas (2001), who added environmental policy dummies to a two-factor model that controlled for size effects in addition to market sensitivity in the U.K. market, and Ziegler, Rennings, and Schröder (2002), who controlled for market risk, company size, and the BV/MV effect in the European market. Both studies found some evidence of a positive association between environmental responsibility and stock performance.

We extend prior portfolio research, particularly Blank and Daniel, by considering advanced performance attribution frameworks and a larger sample.

\section{Measuring Environmental Performance}

Whereas most proxies for environmental performance represent absolute pollution levels, the concept of eco-efficiency is frequently used to measure the environmental performance of a company in a relative sense. Eco-efficiency can be defined as the ratio of the value a company adds (e.g., by producing products) to the waste the company generates by creating that value (see, for instance, Schaltegger, Burritt, and Petersen 2003). To understand the difference between absolute and relative environmental performance, consider, for example, companies that operate in such environmentally sensitive industries as mining, energy, or chemicals. In absolute terms, these companies are typically labeled poor environmental performers. On the ecoefficiency performance measure, however, these companies can still do well relative to their competitors facing the same environmental challenges.

To proxy for corporate eco-efficiency, we obtained rating data from Innovest. The main benefits of these scores are their comprehensiveness. Using more than 20 information sources, both 
quantitative and qualitative in nature, Innovest's analysts evaluate a company relative to its industry peers via an analytical matrix. Companies are evaluated along approximately 60 dimensions, which jointly constitute the final rating. For each of these factors, each company receives a score between 1 and 10. Because these variables are not considered equally important in the overall assessment of ecoefficiency, each factor is weighted differently. For example, a company's environmental product development is usually considered more important than, for instance, outside certification by any nongovernmental organization. The final numerical rating assigned to a company is converted into a relative score based on the total spread of scores in the sector to which the company belongs.

To summarize, the criteria can be grouped into five broad categories, which address five fundamental types of environmental factors (Innovest 2003):

- historical liabilities-risk resulting from previous actions;

- operating risk-risk exposure from recent events;

- sustainability and eco-efficiency risk-future risks initiated by the weakening of the company's material sources of long-term profitability and competitiveness;

- managerial risk efficiency-ability to handle environmental risk successfully; and

- environmentally related strategic profit opportunities-business opportunities available to the company relative to industry peers.

Although the Innovest database contains scores on more than 1,200 companies globally, we considered only U.S. companies. The number of companies was about 180 at the end of May 1997 and increased steadily to approximately 450 at the end of May 2003. All ratings are dated for the month in which they were made available.

\section{Empirical Analysis}

We constructed two mutually exclusive stock portfolios with distinctive eco-efficiency characteristics. ${ }^{2}$ After matching all companies in the Innovest universe with the CRSP stock database, we ranked the companies annually on their most recent ecoefficiency ratings. ${ }^{3}$ The high-ranked (low-ranked) portfolio consists of companies making up the 30 percent of total capitalization rated highest (lowest) by Innovest. The annual reranking and portfolio rebalancing occurred at the end of June. When constructing the portfolios, we took into account a onemonth lag for the ranking data to avoid look-ahead bias. Companies for which no rankings were available at the rebalancing date were excluded automatically for the subsequent 12 -month period.

The Innovest database contains scores only for the 1997-2003 period, but asset-pricing tests require many data points. Therefore, we confronted a small-sample problem. To obtain meaningful results, we extended the July 1997 ratings backward through July 1995. Because ecoefficiency ratings tend to have low variability, we believe that extending the data backward for two years is acceptable. ${ }^{4}$ As a result, we observed endof-month portfolio return data for the period July 1995 through December 2003.

Table 1 gives descriptive statistics for the two portfolios and for a value-weighted portfolio consisting of all stocks in the CRSP database, which is a proxy for the market (as in Fama and French). These basic statistics suggest that the portfolio consisting of highly eco-efficient companies performed better than the eco-inefficient portfolio, even after adjusting for volatility. The low-ranked portfolio also has a substantially lower Sharpe ratio than the market proxy. The last columns of Table 1 report some additional time-series properties. The Ljung-Box $Q$-statistics and corresponding $p$-values

Table 1. Descriptive Statistics for Eco-Efficient-Ranked Portfolios, July 1995-December 2003

\begin{tabular}{lccccccccc}
\hline Portfolio & Mean & Std. Dev & $\begin{array}{c}\text { Sharpe } \\
\text { Ratio }\end{array}$ & $\begin{array}{c}\text { Maximum } \\
\text { Monthly Return }\end{array}$ & $\begin{array}{c}\text { Minimum } \\
\text { Monthly Return }\end{array}$ & AC-Q & HC-Q & Skewness & Kurtosis \\
\hline High-ranked companies & $12.2 \%$ & $17.82 \%$ & 0.46 & $13.06 \%$ & $-12.86 \%$ & 0.25 & 0.44 & -0.42 & 2.95 \\
& & & & & & & $(0.62)$ & $(0.51)$ & \\
Low-ranked companies & 8.87 & 17.01 & 0.28 & 9.95 & -11.48 & 0.00 & 0.98 & -0.31 & 2.65 \\
& & & & & & $(0.98)$ & $(0.32)$ & & \\
Market proxy & 11.31 & 17.07 & 0.42 & 8.33 & -15.69 & 0.16 & 0.01 & -0.7 & 3.21 \\
& & & & & & $(0.69)$ & $(0.93)$ & \\
\hline
\end{tabular}

Notes: The Sharpe ratio is the ratio of the mean excess return to the standard deviation of return. The mean return, the standard deviation, and the Sharpe ratio are annualized. The last four columns provide $Q$-statistics (and corresponding $p$-values in parentheses) for the returns and their variances to test for autocorrelation (AC-Q) and heteroscedasticity (HC-Q) up to one lag; skewness data; and kurtosis data. 
serve as tests for autocorrelation and heteroscedasticity. These test statistics suggest that we cannot reject the null hypothesis of no autocorrelation and no heteroscedasticity up to one lag. ${ }^{5}$ Hence, autocorrelation and heteroscedasticity were not a concern throughout the remainder of our research. The skewness and kurtosis estimates indicate only weak deviation from a normal distribution. ${ }^{6}$

Portfolio Performance in a CAPM Framework. To account for differentials in the portfolios' market risks, we first measured portfolio performance via the well-established CAPM. Specifically, for all portfolios, we used an ordinary least-squares regression to estimate the model of the form:

$$
R_{i t}-R_{f t}=\alpha_{i}+\beta_{i}\left(R_{m t}-R_{f t}\right)+\varepsilon_{i t},
$$

where

$$
\begin{aligned}
R_{i t}= & \text { return on portfolio } i \text { in month } t \\
R_{f t}= & \text { one-month U.S. T-bill rate at } t \\
R_{m t}= & \text { return on a value-weighted market } \\
& \text { proxy in month } t \\
\varepsilon_{i t}= & \text { an error term }
\end{aligned}
$$

The value-weighted market proxy and the risk-free rate were provided by the Kenneth French Data Library. ${ }^{7}$ The model beta, $\beta_{i}$, is interpreted as measuring a portfolio's market-risk exposure, and Jensen's alpha, $\alpha_{i}$, represents the average abnormal return in excess of the return on the market proxy. Hence, this framework implicitly assumes that the difference between the return on a portfolio and the return on the single-factor benchmark provides an accurate estimate of risk-adjusted performance.

Table 2 reports performance evaluation results obtained from the CAPM framework. Because the primary focus of the research is the performance differential between the high-ranked portfolio and the low-ranked portfolio, we provide the returns on a "Difference" portfolio, which was constructed by subtracting the low-ranked portfolio returns from the returns on the high-ranked stock portfolio. The influence of environmental screening on investment performance is the difference between the alpha on the high-ranked portfolio and the alpha on the low-ranked portfolio.

According to the reported alpha estimates and corresponding $t$-statistics, neither portfolio's performance was significantly different from that of the market proxy. Furthermore, a comparison of the betas reveals that the portfolios did not differ significantly in exposure to the market factor. The most important observation is that the alpha of the Difference portfolio is positive (i.e., 3.05 percent annually), which suggests that the high-ranked portfolio provided a higher market risk-adjusted return than its low-ranked counterpart. Although economically large, the performance difference in this framework is not statistically significant.
Table 2. Empirical Results of One-Factor Regressions, July 1995December 2003

\begin{tabular}{lccc}
\hline Portfolio & $\alpha$ & $R_{m}-R_{f t}$ & Adjusted $R^{2}$ \\
\hline High-ranked companies & $\begin{array}{c}1.29 \% \\
(0.51)\end{array}$ & $\begin{array}{c}0.94^{* * *} \\
(22.62)\end{array}$ & 0.82 \\
Low-ranked companies & $\begin{array}{c}-1.76 \\
(-0.86)\end{array}$ & $\begin{array}{c}0.91^{* * *} \\
(15.87)\end{array}$ & 0.83 \\
& 3.05 & 0.04 & 0.00 \\
Difference portfolio & $(1.09)$ & $(0.66)$ & \\
& & & \\
$\begin{array}{l}\text { Industry-adjusted } \\
\text { difference }\end{array}$ & 3.82 & 0.03 & 0.00 \\
& $(1.42)$ & $(0.39)$ & \\
\hline
\end{tabular}

Note: For all portfolios, we estimated the model formally defined by Equation 1. The bottom row reports the results of estimating the difference in industry-adjusted return by using three additional regressors obtained via a principal-components analysis (Equation 2). Coefficients on $I P_{1-3 t}$ are not reported; $t$-statistics (in parentheses) were derived from Newey-West (1987) heteroscedasticity- and autocorrelation-consistent standard errors. Sample alphas are annualized percentages.

* Significant at 10 the percent level.

**Significant at 5 the percent level.

***Significant at 1 the percent level.

DiBartolomeo and Kurtz (1999) provided evidence that sector exposures drive SRI portfolio returns to a great extent; therefore, we also investigated whether our results tend to be industry sensitive. In testing for industry sensitivity, we used an approach similar to that of Pastor and Stambaugh (2002) and Jones and Shanken (2004). This approach, previously applied on socially responsible mutual fund returns by Geczy et al., involves the construction of a factor model composed of the excess market return and three industry factors orthogonal to the primary factor. To derive these regressors, one performs a principal-components analysis on the portion of Fama and French's 30 excess industry-sorted portfolio returns that cannot be explained by the single-factor model (i.e., the model's intercept and the residual series). Subsequently, the first three components, by capturing most remaining industry return variation, are taken to complement the single-factor model. The resultant model is of the form:

$$
R_{i t}-R_{f t}=\alpha_{i}+\beta_{0 i}\left(R_{m t}-R_{f t}\right)+\beta_{1-3 i} I P_{1-3 t}+\varepsilon_{i t},
$$

where $I P_{1-3 t}$ represents three factors (principal components) capturing industry effects.

After performing this regression, we obtained industry bias-free alpha estimates. The results are reported in the bottom row of Table 2 . Note that Table 2 does not report loadings on the industryadjustment variables because these coefficients are 
difficult to interpret. The return on the Difference portfolio after industry adjustment increases to 3.82 percent a year, indicating that the performance estimates reported previously were adversely affected by industry exposures. The model intercept, nonetheless, remains insignificant.

\section{Performance in a Multifactor Framework.}

After empirically establishing the inefficiency of the single-factor CAPM framework, Fama and French introduced a three-factor model that adds to excess market return a capitalization-based factor (smallcap stock returns minus large-cap stocks returns, $\mathrm{SMB}$ ) and a BV/MV factor (stock returns for companies with high BV/MV minus stock returns for companies with low BV/MV, HML). Although the benefits of the three-factor model are acknowledged, the model has been subject to further improvement. For example, examining persistence in U.S. mutual fund performance, Carhart demonstrated that the three-factor model fails to explain the Jegadeesh and Titman (1993) momentum strategy and proposed the addition of a momentum factor (MOM) to existing performance models.

In this section, we report our analysis of the historical monthly return distribution of the two portfolios by means of the multifactor performance model used by Carhart. In using three additional control variables, we mitigated potentially severe biases that could result from style tilts in stock portfolios (size, value versus growth, or momentum effects). ${ }^{8}$ This control is particularly important in light of mounting evidence that the returns on style investment strategies account for a considerable portion of SRI portfolio performance (see, for example, Bauer et al.; Gregory, Matatko, and Luther 1997). As a further adjustment of average returns for industry effects, we extended the industryadjustment process to the multivariate setting by analyzing the residuals derived from a regression of Fama and French's industry-sorted portfolio returns on the four factors.

Formally, the approach to performance assessment entailed estimating the following equations:

$$
\begin{aligned}
R_{i t}-R_{f t}= & \alpha_{i}+\beta_{0 i}\left(R_{m t}-R_{f t}\right)+\beta_{1 i} S M B_{t} \\
& +\beta_{2 i} H M L_{t}+\beta_{3 i} M O M_{t}+\varepsilon_{i t},
\end{aligned}
$$

and

$$
\begin{aligned}
R_{i t}-R_{f t}= & \alpha_{i}+\beta_{0 i}\left(R_{m t}-R_{f t}\right)+\beta_{1 i} S M B_{t}+\beta_{2 i} H M L_{t} \\
& +\beta_{3 i} M O M_{t}+\beta_{4-6 i} I P_{1-3 t}+\varepsilon_{i t} .
\end{aligned}
$$

where

$S M B_{t}=$ return difference between a small-cap portfolio and a large-cap portfolio in month $t$
$H M L_{t}=$ return difference between a value (high-BV/MV) portfolio and a growth (low-BV/MV) portfolio in month $t$

$M O M_{t}=$ return difference between a portfolio of past 12-month "winners" and a portfolio of past 12-month "losers" in month $t$

$S M B$ and HML data were obtained from the Kenneth French Data Library; the MOM data came from Carhart.

Table 3 reports performance estimates resulting from estimation of the four-factor model (Equation 3). Table 3 has several prominent differences with Table 2 . First, the adjusted $R^{2}$ s from the models have increased. This observation confirms the incremental explanatory power of a multivariate framework. Second, the high-ranked portfolio is reported to have earned a significant average factor-adjusted return of 3.98 percent a year, whereas the lowranked portfolio performed poorly. Third, factor loadings on the additional determinants, $S M B$, $H M L$, and $M O M$, are generally significant. For both the high-ranked portfolio and the low-ranked portfolio, the coefficient on $S M B$ is significantly negative, which implies a bias toward large-cap stocks in the Innovest database. The factor loadings on $H M L$ suggest that the high-ranked portfolio was somewhat growth-stock oriented during the period examined whereas the low-ranked portfolio was significantly tilted toward value stocks.

Note also the significantly negative coefficients on the momentum factor. They suggest that both stocks with relatively bad past-year performance and those with good past-year performance tend to have relatively poor eco-efficiency rankings, which seems counterintuitive. Because prior related studies revealed evidence of a positive relationship between financial performance and subsequent social performance (e.g., Chung, Eneroth, and Schneeweis 2003), we expected the highranked portfolio to be positively related to the momentum factor.

Results with regard to the Difference portfolio show that the performance differential between the two portfolios, 5.06 percent a year for the full period after adjusting for multiple factor loadings, is also significant at the 10 percent level (and almost significant at the 5 percent level).

Table 3 also reports some subsample analyses we conducted on the Difference portfolio to allow for the possibility that the stock market crash of March 2000 introduced a structural break in the data. Subsample results for this portfolio suggest that the influence of the crash was negligible. The subsample alphas remain economically largemore than 6 percent a year. And, in spite of the 
Table 3. Multifactor Regression Results

\begin{tabular}{|c|c|c|c|c|c|c|}
\hline Portfolio & $\alpha$ & $R_{m}-R_{f t}$ & $S M B$ & $H M L$ & MOM & Adjusted $R^{2}$ \\
\hline $\begin{array}{l}\text { High-ranked companies } \\
\text { (full period) }\end{array}$ & $\begin{array}{l}3.98 \%{ }^{*} \\
(1.93)\end{array}$ & $\begin{array}{l}0.90^{* * *} \\
(25.02)\end{array}$ & $\begin{array}{l}-0.22^{* * *} \\
(-4.30)\end{array}$ & $\begin{array}{l}-0.08 \\
(-1.16)\end{array}$ & $\begin{array}{l}-0.10^{* * *} \\
(-5.99)\end{array}$ & 0.87 \\
\hline $\begin{array}{l}\text { Low-ranked companies } \\
\text { (full period) }\end{array}$ & $\begin{array}{l}-1.08 \\
(-0.55)\end{array}$ & $\begin{array}{l}0.95^{* * *} \\
(19.09)\end{array}$ & $\begin{array}{l}-0.15^{* * *} \\
(-3.70)\end{array}$ & $\begin{array}{l}0.11^{* *} \\
(2.29)\end{array}$ & $\begin{array}{l}-0.08^{* * *} \\
(-2.62)\end{array}$ & 0.88 \\
\hline \multicolumn{7}{|l|}{ Difference portfolio } \\
\hline Full period & $\begin{array}{l}5.06^{*} \\
(1.86)\end{array}$ & $\begin{array}{l}-0.05 \\
(-0.80)\end{array}$ & $\begin{array}{l}-0.07 \\
(-0.95)\end{array}$ & $\begin{array}{l}-0.19^{* *} \\
(-2.20)\end{array}$ & $\begin{array}{l}-0.02 \\
(-0.43)\end{array}$ & 0.01 \\
\hline July 1995-February 2000 & $\begin{array}{l}6.21^{*} \\
(1.71)\end{array}$ & $\begin{array}{l}0.00 \\
(0.04)\end{array}$ & $\begin{array}{c}0.01 \\
(0.08)\end{array}$ & $\begin{array}{c}0.12 \\
(0.95)\end{array}$ & $\begin{array}{c}0.07 \\
(1.16)\end{array}$ & 0.03 \\
\hline March 2000-December 2003 & $\begin{array}{l}6.71^{*} \\
(1.84)\end{array}$ & $\begin{array}{l}-0.06 \\
(-0.62)\end{array}$ & $\begin{array}{l}-0.11 \\
(-0.97)\end{array}$ & $\begin{array}{l}-0.32^{* * *} \\
(-2.96)\end{array}$ & $\begin{array}{l}-0.01 \\
(-0.29)\end{array}$ & 0.13 \\
\hline $\begin{array}{l}\text { Industry-adjusted difference } \\
\text { (full period) }\end{array}$ & $\begin{array}{l}6.04^{* *} \\
(2.38)\end{array}$ & $\begin{array}{l}-0.20^{*} \\
(-1.79)\end{array}$ & $\begin{array}{l}-0.14^{*} \\
(-1.87)\end{array}$ & $\begin{array}{l}-0.30^{* *} \\
(-2.18)\end{array}$ & $\begin{array}{l}-0.01 \\
(-0.18)\end{array}$ & 0.01 \\
\hline
\end{tabular}

Notes: Full period is July 1995-December 2003. For all but bottom row, see Equation 3. The equation for the bottom row is Equation 4 in the text with the IP variable modified as follows: $R_{i t}-R_{f t}=\alpha_{i}+$ $\beta_{0 i}\left(R_{m t}-R_{f t}\right)+\beta_{1 i} S M B_{t}+\beta_{2 i} H M L_{t}+\beta_{3 i} M O M_{t}+\beta_{4-6 i} I P_{1-3 t}+\varepsilon_{i t}$. Coefficients on $I P_{4-6 t}$ are not reported; $t$-statistics (in parentheses) were derived from Newey-West heteroscedasticity- and autocorrelationconsistent standard errors. Alphas are annualized percentages.

* Significant at the 10 percent level.

** Significant at the 5 percent level.

*** Significant at the 1 percent level.

small samples, the alphas remain statistically significant, at the 10 percent level.

As for the factor loadings, the results confirm that there are significant differences in styles or risk sensitivities between the two extreme portfolios. In line with the outcomes within the CAPM framework, the two portfolios do not significantly differ in exposure to market risk. Only with respect to $H M L$ does the Difference portfolio exhibit a significant factor exposure.

The bottom row in Table 3 reports coefficients estimated by Equation 4-that is, the seven-factor model that additionally controls for industry tilts. These results show that after industry effects are taken into account, the difference in performance between the high-ranked portfolio and the lowranked portfolio increases slightly (to 6.04 percent a year) and becomes statistically significant at the 5 percent level. Perhaps remarkably, differences in factor loadings between the two portfolios also become more pronounced after industry effects are removed. We see significant differences in market sensitivity and exposure with respect to $S M B$ and $H M L$.

Note, however, that the interpretation of performance results can be overly driven by various parameters in the measurement process that have been specified exogenously. Therefore, continuing with the analysis of industry-adjusted returns, we "endogenized" some of these parameters by considering alternative portfolio construction methodologies and return calculations. The empirical results of these robustness checks are reported in Table 4 .

In the first row of Table 4, we report the outcome of estimating the seven-factor model but using equal-weighted (instead of value-weighted) industry-adjusted portfolio returns. The performance gap between the high-ranked portfolio and its low-ranked counterpart, as represented by the Difference portfolio, narrows to 2.17 percent from the 6.04 percent of Table 3 , indicating that alpha depends more on large-cap stocks than on smallcap stocks. Portfolio construction based on equal weighting is uncommon, however, in practice.

In the analysis of value-weighted industryadjusted returns, we also found that the results were somewhat sensitive to changes in portfolio formation. The second and third rows in Table 4, which report the results of using size deciles of, respectively, 20 percent and 40 percent of total capitalization, reveal different outcomes from the results of the initial scenario (30 percent breakdowns). When 20 percent quintiles were used, thereby increasing the distinction in environmental performance between the highest and lowest ranked portfolios, the performance gap widened 
Table 4. Robustness Analysis: Results under Alternative Methodologies, July 1995-December 2003

\begin{tabular}{lcccccc}
\hline $\begin{array}{l}\text { Industry-Adjusted } \\
\text { Difference Portfolio }\end{array}$ & $\alpha$ & $R_{m}-R_{f t}$ & $S M B$ & $H M L$ & MOM & Adjusted $R^{2}$ \\
\hline Equal weighting & $2.17 \%$ & -0.10 & $-0.15^{* * *}$ & $-0.12^{*}$ & -0.01 & 0.18 \\
& $(1.11)$ & $(-1.08)$ & $(-3.33)$ & $(-1.75)$ & $(-0.41)$ & \\
$20 \%$ portfolios & $8.60^{* * *}$ & -0.21 & -0.09 & -0.23 & 0.01 & -0.04 \\
& $(2.83)$ & $(-1.40)$ & $(-1.21)$ & $(-1.36)$ & $(0.28)$ & \\
$40 \%$ portfolios & $4.69^{* *}$ & $-0.31^{* *}$ & $-0.22^{* * *}$ & $-0.28^{* *}$ & 0.01 & 0.06 \\
& $(2.40)$ & $(-2.62)$ & $(-3.41)$ & $(-1.98)$ & $(0.51)$ & \\
Sensitive sectors only & $4.47^{* *}$ & $-0.17^{* *}$ & $-0.14^{* * *}$ & $-0.24^{* *}$ & $0.09^{* * *}$ & 0.15 \\
& $(2.07)$ & $(-2.25)$ & $(-2.72)$ & $(-2.60)$ & $(3.77)$ & \\
\hline
\end{tabular}

Notes: Results are for Equation 4 with changes in portfolio construction or return calculation. Alphas are annualized percentages; $t$-statistics (in parentheses) were derived from Newey-West heteroscedasticity- and autocorrelation-consistent standard errors.

\footnotetext{
* Significant at the 10 percent level

** Significant at the 5 percent level.

*** Significant at the 1 percent level.
}

from the 6.04 percent of Table 3 to 8.60 percent. When portfolios covering 40 percent of total market value were used, the performance of the Difference portfolio fell to 4.69 percent. In both cases, however, the excess return remained significant from both an economic and a statistical perspective.

Finally, we computed alphas for portfolios comprising only stocks from environmentally sensitive industries (electric utilities, chemistry, metal and mining, paper and forest products, aerospace and defense, and petroleum). The last row in Table 4 shows that the industry-adjusted performance differential fell to 4.47 percent, but it remained statistically significant at the 5 percent level. A relatively lower alpha for SRI strategies pertaining only to environmentally sensitive industries is remarkable because environmental performance expenditures in these industries are usually substantial.

Overall, we found that companies that perform relatively well along environmental dimensions collectively provide superior returns. The average return on the Difference portfolio is economically large and statistically significant on a risk-, style-, and industry-neutral basis. In terms of statistical significance, the premium estimate is reasonably robust to variations in methodology. Therefore, the results as a whole corroborate the notion that environmentally responsible investing provides benefits.

Our findings also, however, call for an important discussion of the eco-efficiency premium. Given that efforts to correct for investment style and industry bias fail to explain the observed performance differential, what is the nature of the eco-efficiency premium? Is the observed performance gap attributable to latent risk factors or to mispricing?
Many so-called anomalies, such as the size effect (Banz 1981), the value premium (Fama and French), and the momentum anomaly (Jegadeesh and Titman) have become the subject of considerable debate. Many scholars suggest that most return anomalies can be interpreted as proxies for various forms of risk (see Fama and French; Vassalou and Xing 2004; Pastor and Stambaugh 2003); others attribute the observed effects to market inefficiencies (see Lakonishok, Shleifer, and Vishny 1994; Haugen and Baker 1996).

Contrary to these well-documented return premiums, however, the eco-efficiency premium is difficult to explain within the well-known riskreturn paradigm. ${ }^{9}$ We also found it difficult to attribute the results to deficiencies in the performance attribution analysis, because our results are robust to, if not strengthened by, the inclusion of factors that controlled for investment risk, investment style, and severe industry effects.

The alternative explanation-as in Lakonishok et al. and in Haugen and Baker-is that our findings are the result of the market's inability to price ecoefficiency in an efficient manner. This interpretation could also explain the reduction of the eco-efficiency premium observed within environmentally sensitive industries. In environmentally sensitive sectors, where eco-efficiency is arguably a significant driver of future corporate performance, investors are more likely to factor environment-related information into investment decisions. In sectors where the benefits of eco-efficiency are less obvious, corporate eco-efficiency information may be priced inappropriately by financial market participants. 


\section{Practical Implications}

We have shown that a portfolio comprising stocks of companies ranked high as to eco-efficiency outperforms its low-ranked counterpart after adjusting returns for market risk, investment style, and industry effects. Obtaining evidence by adjusting returns after the fact may not be very useful, however, from an investor's perspective. Therefore, in this section, we outline the economic implications of our findings by demonstrating how one can construct an environmentally responsible investment portfolio under practical conditions. To take into account our evidence that industry tilts greatly influence portfolio performance, we constructed an SRI portfolio based on "best-in-class" analysis, an approach that is commonly applied in the SRI industry.

We first used Fama and French's industry classification scheme to identify 12 industries. ${ }^{10}$ In each group, we first ranked all the companies in our dataset by their eco-efficiency scores. Within each industry, we then constructed a value-weighted portfolio of high-ranked stocks and a portfolio of low-ranked stocks. As a general rule, the two portfolios were equal in size-namely, 30 percent of total capitalization-and mutually exclusive. Occasionally, however, when the number of companies within an industry was limited, companies were assigned to both the high-ranked group and the lowranked alternative to maintain a balance in the portfolios' asset sizes. Based on the ratio of total industry capitalization to total market value of all companies in the NYSE/Amex/NASDAQ universe, we computed 12 industry weights. Finally, we assigned these weights to our subportfolios to obtain a bestin-class portfolio and a worst-in-class portfolio.

Summary statistics on the portfolios are reported in Table 5. The best-in-class portfolio (before transaction costs) outperformed the worstin-class portfolio by about 3 percentage points. The portfolio Sharpe ratios indicate that the performance difference persisted after adjusting for volatility. Notice also that the worst-in-class portfolio comprised more companies and exhibited a higher turnover than the best-in-class portfolio.
Figure 1 shows the cumulative absolute return over time for the two portfolios. The cumulative performance difference between the high-ranked portfolio and the low-ranked portfolio was substantial at the end of the observation period (i.e., approximately $66 \mathrm{pps}$ ), but the return gap widened predominantly during the second half of the observation window.

\section{Figure 1. Cumulative Returns of Two Port- folios, July 1995-December 2003}

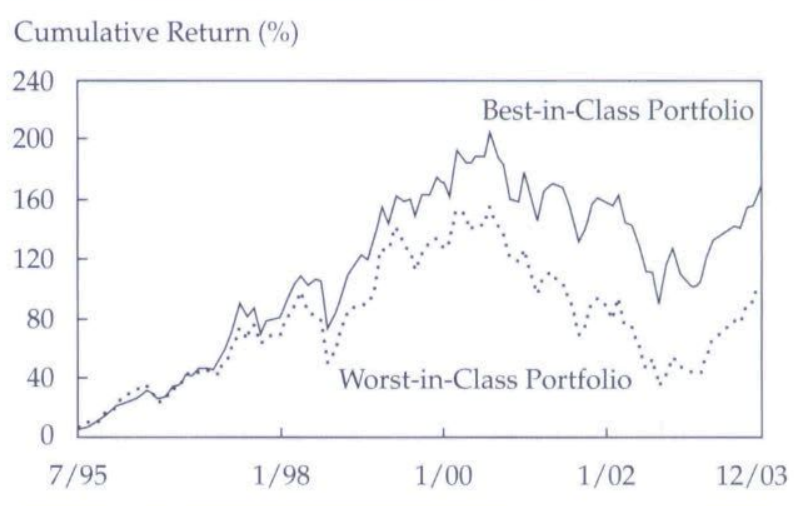

Table 6 reports performance results in the CAPM framework (Equation 1) for the two portfolios under several transaction-cost scenarios. ${ }^{11} \mathrm{As}$ in previous cases, we report alphas and factor loadings for the long position on the best-in-class portfolio, the long position on the worst-in-class portfolio, and the Difference portfolio (the worst-in-class portfolio returns subtracted from the best-in-class returns). Additionally, we evaluated a zero-investment strategy that went long on the high-ranked portfolio and short on the low-ranked portfolio. The long-short portfolio return was computed as the return on the Difference portfolio with zero transaction costs minus the sum of transaction costs associated with each of the two positions.

On a market risk-adjusted basis, the alpha computed for the Difference portfolio (3.55 percent) is significant at the 10 percent level. Notice that this performance difference resembles the one reported previously in Table 2 .

Table 5. Descriptive Statistics for Best-in-Class and Worst-in-Class Portfolios, July 1995-December 2003

\begin{tabular}{lccccc}
\hline Portfolio & $\begin{array}{c}\text { Mean } \\
\text { Return }\end{array}$ & Std. Dev. & Sharpe Ratio & $\begin{array}{c}\text { Average } \\
\text { Turnover }\end{array}$ & $\begin{array}{c}\text { Average No. } \\
\text { of Companies }\end{array}$ \\
\hline Best-in-class & $13.07 \%$ & $17.23 \%$ & 0.53 & $19.67 \%$ & 88 \\
Worst-in-class & 9.88 & 18.04 & 0.33 & 28.65 & 163 \\
\hline
\end{tabular}

Note: The mean return, the standard deviation, and the Sharpe ratio are annualized. 
Table 6. Market Risk-Adjusted Returns in Different Transaction-Cost Scenarios, July 1995-December 2003

\begin{tabular}{lccccccc}
\hline & \multirow{2}{*}{$\begin{array}{c}\alpha \text { at } 0 \\
\text { Transaction }\end{array}$} & & \multicolumn{3}{c}{$\alpha$ at Transaction Costs of: } \\
\cline { 3 - 8 } Portfolio & Costs & $R_{m}-R_{f}$ & Adjusted $R^{2}$ & $50 \mathrm{bps}$ & $100 \mathrm{bps}$ & $150 \mathrm{bps}$ & $200 \mathrm{bps}$ \\
\hline Best-in-class & $2.46 \%$ & $0.91^{* * *}$ & 0.83 & $2.30 \%$ & $2.15 \%$ & $2.00 \%$ & $1.85 \%$ \\
Worst-in-class & $(1.15)$ & $(20.78)$ & & $(1.07)$ & $(1.00)$ & $(0.93)$ & $(0.86)$ \\
& -1.09 & $0.96^{* * *}$ & 0.84 & -1.31 & -1.54 & -1.76 & -1.98 \\
Difference & $(-0.44)$ & $(19.96)$ & & $(-0.53)$ & $(-0.62)$ & $(-0.71)$ & $(-0.79)$ \\
& $3.55^{*}$ & -0.05 & 0.00 & $3.62^{*}$ & $3.69^{*}$ & $3.76^{*}$ & $3.82^{*}$ \\
Long-short strategy & $(1.85)$ & $(-1.20)$ & & $(1.88)$ & $(1.91)$ & $(1.94)$ & $(1.97)$ \\
& $3.55^{*}$ & -0.05 & 0.00 & 3.18 & 2.80 & 2.43 & 2.05 \\
& $(1.85)$ & $(-1.20)$ & & $(1.65)$ & $(1.45)$ & $(1.25)$ & $(1.05)$ \\
\hline
\end{tabular}

Notes: Transactions costs are round-trip costs. The long-short portfolio return is the return on the Difference portfolio with no transaction costs minus of the sum of transaction costs associated with each of the two positions. Alphas are annualized percentages; $t$-statistics (in parentheses) were derived from Newey-West heteroscedasticity- and autocorrelation-consistent standard errors.

\footnotetext{
* Significant at the 10 percent level.

**Significant at the 5 percent level.

*** Significant at the 1 percent level.
}

Furthermore, the difference in performance between the two portfolios is also robust to the introduction of transaction costs. In fact, an increase in transaction costs leads to a widening of the return gap because the worst-in-class portfolio suffered from a higher turnover rate than the bestin-class portfolio. For example, in the $200 \mathrm{bp}$ cost scenario, the return on the Difference portfolio is 3.83 percent on a market risk-adjusted basis.

Performance evaluation results for the longshort strategy underline the difficulties of longshort investing in the presence of transaction costs. As the level of transaction costs gradually increased from 0 to $200 \mathrm{bps}$, the long-short investment strategy experienced a decrease in risk-adjusted return. The statistical significance of alpha also fell.

Table 7 reports the outcomes of using Equation 3 for multivariate performance attribution analysis. As expected, the results are generally more pronounced after controlling for style bias. In the absence of transaction costs, the best-in-class portfolio outperformed the worst-in-class portfolio with an alpha for the Difference portfolio of almost 6 percent that is significant at the 5 percent level. Again, note that this performance estimate is similar to the one reported in Table 3.

Table 7. Multifactor-Adjusted Returns under Different Transaction Cost Scenarios, July 1995December 2003

\begin{tabular}{|c|c|c|c|c|c|c|c|c|c|c|}
\hline \multirow[b]{2}{*}{ Portfolio } & \multirow{2}{*}{$\begin{array}{c}\alpha \text { at } 0 \\
\text { Transaction } \\
\text { Costs }\end{array}$} & \multirow[b]{2}{*}{$R_{m}-R_{f}$} & \multirow[b]{2}{*}{$S M B$} & \multirow[b]{2}{*}{$H M L$} & \multirow[b]{2}{*}{ MOM } & \multirow[b]{2}{*}{ Adjusted $R^{2}$} & \multicolumn{4}{|c|}{$\alpha$ at Transaction Costs of: } \\
\hline & & & & & & & 50 bps & $100 \mathrm{bps}$ & $150 \mathrm{bps}$ & $200 \mathrm{bps}$ \\
\hline \multirow[t]{2}{*}{ Best-in-class } & $4.15 \% * *$ & $0.92^{* * *}$ & $-0.19^{* * *}$ & 0.02 & $-0.09^{* * *}$ & 0.88 & $3.97 \% * *$ & $3.79 \% *$ & $3.61 \% *$ & $3.43 \% *$ \\
\hline & $(2.11)$ & $(24.15)$ & $(-4.14)$ & $(0.26)$ & $(-5.31)$ & & $(2.02)$ & $(1.92)$ & $(1.82)$ & $(1.72)$ \\
\hline \multirow[t]{2}{*}{ Worst-in-class } & -1.81 & $1.03^{* * *}$ & 0.04 & $0.23^{* * *}$ & $-0.08^{* * *}$ & 0.86 & -2.06 & -2.31 & -2.56 & -2.80 \\
\hline & $(-0.77)$ & $(27.49)$ & $(0.93)$ & $(4.59)$ & $(-2.86)$ & & $(-0.88)$ & $(-0.98)$ & $(-1.09)$ & $(-1.20)$ \\
\hline \multirow[t]{2}{*}{ Difference } & $5.96^{* *}$ & $-0.12^{* * *}$ & $-0.23^{* * *}$ & $-0.22^{* * *}$ & -0.01 & 0.17 & $6.02 * *$ & $6.10^{* *}$ & $6.16^{* *}$ & $6.23^{* *}$ \\
\hline & $(2.54)$ & $(-3.02)$ & $(-3.82)$ & $(-3.52)$ & $(-0.20)$ & & (2.56) & $(2.58)$ & $(2.60)$ & $(2.62)$ \\
\hline \multirow[t]{2}{*}{ Long-short strategy } & $5.96^{* *}$ & $-0.12^{* * *}$ & $-0.23^{* * *}$ & $-0.22^{* * *}$ & -0.01 & 0.17 & $5.53^{* *}$ & $5.10^{* *}$ & $4.68^{*}$ & $4.25^{*}$ \\
\hline & $(2.54)$ & $(-3.02)$ & $(-3.82)$ & $(-3.52)$ & $(-0.20)$ & & $(2.34)$ & $(2.14)$ & (1.94) & (1.73) \\
\hline
\end{tabular}

Note: See notes to Table 6.

* Significant at the 10 percent level.

** Significant at the 5 percent level.

*** Significant at the 1 percent level. 
In the presence of transaction costs, the excess return on the best-in-class portfolio remained statistically significant. For instance, even in the scenario of $200 \mathrm{bp}$ transaction costs, we found that the annualized alpha of the best-in-class portfolio is still large (3.43 percent) and statistically significant at the 10 percent level. Unsurprisingly, the factor-adjusted return on the Difference portfolio is statistically significant at the 5 percent level in all transaction-cost scenarios. Table 7 also reports that the performance of the long-short portfolio was much better when we controlled not only for market risk but also for style tilts. All four-factor alphas are significant at standard levels regardless of the assumed level of transaction costs.

In brief, our results suggest that various practical ways to exploit the eco-efficiency premium are available. Which investment approach would be best is, however, difficult to say. Generally, the liquidity of the stocks, trading costs, the presence of short-sales constraints, an investor's attitude toward short selling, and the investor's style preference play important roles in determining the optimal strategy. Liquidity was a minor issue in the context of the SRI strategies in our study because the eco-efficient companies were the larger companies. As for trading costs, although we have examined them in general, a practitioner would be wise to carry out a more detailed analysis of potential trading costs of specific stocks before making investment decisions. Keim and Madhavan (1997), for example, documented variations in trading costs among institutions, investment styles, and markets. Short-selling constraints may limit investors' abilities to exploit the eco-efficiency premium by using long-short positions, but the results provided here suggest that long positions in a simple best-in-class strategy are also capable of producing significant alpha under practical circumstances. Finally, given the importance of size and style factors in explaining the SRI portfolio returns, implementing SRI not only on an industry-balanced basis but also on a style-neutral basis could be incrementally valuable.

\section{Conclusion}

Although conventional investment theory predicts that investors should be cautious about adopting SRI, we presented evidence that a stock portfolio consisting of large-cap companies labeled "most eco-efficient" sizably outperformed a less ecoefficient portfolio over the 1995-2003 period. Using several enhanced performance attribution models to overcome methodological concerns, we showed that the observed performance difference cannot be explained by differences in market sensitivity, investment style, or industry bias. Even in the presence of transaction costs, a simple best-inclass stock selection strategy historically earned a higher market risk-adjusted and style-adjusted return of 6 pps than a worst-in-class portfolio. Overall, our findings suggest that the benefits of considering environmental criteria in the investment process can be substantial.

Our results are puzzling because it is difficult to reconcile the observed performance differential with the well-established return-risk paradigm. The fact that common risk factors fail to account fully for the observed results raises the possibility of a mispricing story. Testing a mispricing hypothesis, however, is beyond the scope of this article. We leave our findings open to interpretation and encourage future research to concentrate on longer time-series data and to present complementary evidence from different countries.

We are grateful to Innovest Strategic Value Advisors for supplying us its eco-efficiency database and to Mark Bremmer for helpful comments. We also thank Mark Carhart and Kenneth French for providing the benchmark portfolio returns and Vishal Jadnanansing for helpful suggestions and data assistance. We appreciate some computational support by Joop Huij. The financial support of Inquire Europe is gratefully acknowledged. The views expressed in this article are not necessarily shared by ABP Investments.

\section{Notes}

1. Literature on the performance of U.S. SRI mutual funds and or SRI indexes includes Bauer, Koedijk, and Otten (forthcoming 2005), Hamilton, Jo, and Statman (1993), Statman (2000), Sauer (1997), and Geczy, Stambaugh, and Levin (2003).

2. Note that the sorting approach used in this study does not allow for an explicit judgment on the direction of causality between environmental and financial variables. We are concerned with the long-term correlation of environmental criteria and investment returns.
3. Matching occurred by ticker, company name, and CUSIP number. Because the CRSP database is survivor-bias free, we were able to analyze the returns for companies that disappeared during the sample period (e.g., as a result of merger or bankruptcy).

4. We are aware that this procedure potentially introduces look-ahead bias. In addition to the ratings' low variability, however, the results when we used real data for the 19972003 period are similar to those reported here. These results are available upon request. 
5. When multiple lags were considered, we also did not detect autocorrelation and heteroscedasticity at other lags.

6. In most cases, a Jarque-Bera nonparametric test of normality did not reject the null hypothesis of a normally distributed series.

7. Available at mba.tuck.dartmouth.edu/pages/faculty/ken. french/data_library.html.

8. Although there is an ongoing discussion about whether these additional factors proxy for risk, we bypass that subject and merely use the factor-mimicking portfolio returns as control variables in performance estimation.
9. Strictly speaking, this suggestion means the returns to our strategy can be interpreted as an anomaly instead of a premium.

10. We assigned companies to one of the following industries: consumer durables, consumer nondurables, manufacturing, energy, chemical, business equipment, telephone and television, utilities, shops, health, money/finance, and all remaining.

11. Because best-in-class and worst-in-class strategies are industry neutral in nature, we did not consider the model given by Equation 2.

\section{References}

Banz, Rolf W. 1981. "The Relationship between Return and Market Value of Common Stocks." Journal of Financial Economics, vol. 9, no. 1 (March):3-18.

Bauer, Rob, Kees Koedijk, and Rogér Otten. Forthcoming 2005. "International Evidence on Ethical Mutual Fund Performance and Investment Style." Journal of Banking and Finance.

Blank, Herbert D., and Wayne E. Daniel. 2002. "The EcoEfficiency Anomaly." Innovest Strategic Value Advisors (June): www.innovestgroup.com/pdfs/Eco_Anomaly_7_02.pdf.

Carhart, Mark M. 1997. "On the Persistence in Mutual Fund Performance." Journal of Finance, vol. 52, no. 1 (March):57-82.

Chen, Kung H., and Richard W. Metcalf. 1980. "The Relationship between Pollution Control Record and Financial Indicators Revisited." Accounting Review, vol. 55, no. 1 (January):168-177.

Chung, Sam Y., Kristina Eneroth, and Thomas Schneeweis. 2003. "Corporate Reputation and Investment Performance: The UK and US Experience." Research in International Business and Finance, vol. 17:273-291.

Cohen, Mark A., Scott A. Fenn, and Shameek Konar. 1997. "Environmental and Financial Performance: Are They Related?" Working paper, Vanderbilt University.

DiBartolomeo, Dan, and Lloyd Kurtz. 1999. "Managing Risk Exposures of Socially Screened Portfolios." Working paper, Northfield Information Services.

Diltz, David J. 1995. "Does Social Screening Affect Portfolio Performance?" Journal of Investing, vol. 4, no. 1 (Spring):64-69.

Fama, Eugene F., and Kenneth R. French. 1993. "Common Risk Factors in the Returns on Stocks and Bonds." Journal of Financial Economics, vol. 33, no. 1 (January):3-56.

Geczy, Christopher, Robert F. Stambaugh, and David Levin. 2003. "Investing in Socially Responsible Mutual Funds." Working paper, Wharton School, University of Pennsylvania (May).

Gregory, Alan, John Matatko, and Robert Luther. 1997. "Ethical Unit Trust Financial Performance: Small Company Effects and Fund Size Effects." Journal of Business Finance and Accounting, vol. 24 , no. 5 (June):705-725.

Griffin, Jennifer J., and John F. Mahon. 1997. "The Corporate Social Performance and Corporate Financial Performance Debate: Twenty-Five Years of Incomparable Research." Business E Society, vol. 36, no. 1 (March):5-31.

Guerard, John B., Jr. 1997. "Additional Evidence on the Cost of Being Socially Responsible in Investing." Journal of Investing, vol. 6 , no. 4 (Winter):31-35.

Hamilton, James T. 1995. "Pollution as News: Media and Stock Market Reactions to the Toxics Release Inventory Data." Journal of Environmental Economics and Management, vol. 28, no. 1 (January):98-113.
Hamilton, Sally, Hoje Jo, and Meir Statman. 1993. "Doing Well While Doing Good? The Investment Performance of Socially Responsible Mutual Funds." Financial Analysts Journal, vol. 49, no. 6 (November/December):62-66.

Haugen, Robert A., and Nardin L. Baker. 1996. "Commonality in the Determinants of Expected Stock Returns." Journal of Financial Economics, vol. 41, no. 3 (July):401-439.

Innovest. 2003. "New Alpha Source for Asset Managers: Environmentally-Enhanced Investment Portfolios." Innovest Strategic Value Advisors Executive Summary: www. innovestgroup.com.

Jegadeesh, N., and S. Titman. 1993. "Returns to Buying Winners and Selling Losers: Implications for Stock Market Efficiency." Journal of Finance, vol. 48, no. 1 (March):65-91.

Jones, Christopher S., and Jay Shanken. 2004. "Mutual Fund Performance with Learning across Funds." Unpublished working paper.

Keim, Donald B., and Ananth Madhavan. 1997. "Transactions Costs and Investment Style: An Inter-Exchange Analysis of Institutional Equity Trades." Journal of Financial Economics, vol. 46, no. 3 (December):265-292.

Klassen, Robert D., and Curtis P. McLaughlin. 1996. "The Impact of Environmental Management on Firm Performance." Management Science, vol. 42, no. 8 (August):1199-1214.

Konar, Shameek, and Mark A. Cohen. 2001. "Does the Market Value Environmental Performance?" Review of Economics and Statistics, vol. 83, no. 2 (May):281-289.

Lakonishok, Joseph, Andrei Shleifer, and Robert W. Vishny. 1994. "Contrarian Investment, Extrapolation and Risk." Journal of Finance, vol. 49, no. 5 (December):1541-78.

Mahapatra, Sitikantha. 1984. "Investor Reaction to a Corporate Social Accounting." Journal of Business Finance and Accounting, vol. 11, no. 1 (January):29-40.

Newey, Whitney K., and Kenneth D. West. 1987. "A Simple, Positive Semi-Definite Heteroskedasticity and Autocorrelation Consistent Variance Covariance Matrix." Econometrica, vol. 55, no. 3 (May):703-708.

Pastor, Lubos, and Robert F. Stambaugh. 2002. "Mutual Fund Performance and Seemingly Unrelated Assets." Journal of Financial Economics, vol. 63, no. 3 (March):313-349.

- 2003. "Liquidity Risk and Expected Stock Returns." Journal of Political Economy, vol. 111, no. 3 (June):642-685.

Porter, Michael E., and Claas van der Linde. 1995. "Green and Competitive. Ending the Stalemate." Harvard Business Review (September-October):120-135. 
Rao, Spuma M. 1996. "The Effect of Published Reports of Environmental Pollution on Stock Prices." Journal of Financial and Strategic Decisions, vol. 9, no. 1 (Spring):25-32.

Sauer, David A. 1997. "The Impact of Social-Responsibility Screens on Investment Performance: Evidence from the Domini 400 Social Index and Domini Equity Mutual Fund." Review of Financial Economics, vol. 6, no. 2:137-149.

Schaltegger, Stefan, Roger Burritt, and Holger Petersen. 2003. An Introduction to Corporate Environmental Management: Striving for Sustainability. Sheffield, U.K.: Greenleaf Publishing.

Shane, Philip B., and Barry H. Spicer. 1983. "Market Response to Environmental Information Produced outside the Firm." Accounting Review, vol. 58, no. 3 (July):521-538.

Sharpe, William F. 1964. "Capital Asset Prices: A Theory of Market Equilibrium under Conditions of Risk." Journal of Finance, vol. 19, no. 3 (September):425-442.

Social Investment Forum. 2001. "2001 Report on Socially Responsible Investing Trends in the United States." Social Investment Forum Foundation and Social Investment Forum: www.socialinvest.org.

Spicer, Barry H. 1978. "Investors, Corporate Social Performance and Information Disclosure: An Empirical Study." Accounting Review, vol. 53, no. 1 (January):94-111.

Statman, Meir. 2000. "Socially Responsible Mutual Funds." Financial Analysts Journal, vol. 56, no. 3 (May/June):30-39.
Thomas, Alison. 2001. "Corporate Environmental Policy and Abnormal Stock Price Returns: An Empirical Investigation." Business Strategy and the Environment, vol. 10, no. 3 (May/ June):125-134.

Ullman, Arieh E. 1985. "Data in Search of a Theory: A Critical Examination of the Relationships among Social Performance, Social Disclosure, and Economic Performance of U.S. Firms." Academy of Management Review, vol. 10, no. 3 (July):540-557.

Vassalou, Maria, and Yuhang Xing. 2004. "Default Risk in Equity Returns." Journal of Finance, vol. 59, no. 2 (April):831-868.

Wagner, Marcus. 2001. "A Review of Empirical Studies Concerning the Relation between Environmental and Economic Performance: What Does the Evidence Tell Us?" Center for Sustainability Management.

Walley, Noah, and Bradley Whitehead. 1994. "It's Not Easy Being Green." Harvard Business Review (May-June):46-52.

White, Mark A. 1996. "Corporate Environmental Performance and Shareholder Value." Working Paper WHI002, McIntire School of Commerce.

Yamashita, Miwaka, Swapan Sen, and Mark C. Roberts. 1999. "The Rewards for Environmental Conscientiousness in the U.S. Capital Markets." Journal of Financial and Strategic Decisions, vol. 12, no. 1 (Spring):73-82.

Ziegler, Andreas, Klaus Rennings, and Michael Schröder. 2002. "The Effect of Environmental and Social Performance on the Shareholder Value of European Stock Corporations." Working paper, Centre for European Economic Research.

\section{Guides to grow your business and portfolio.}

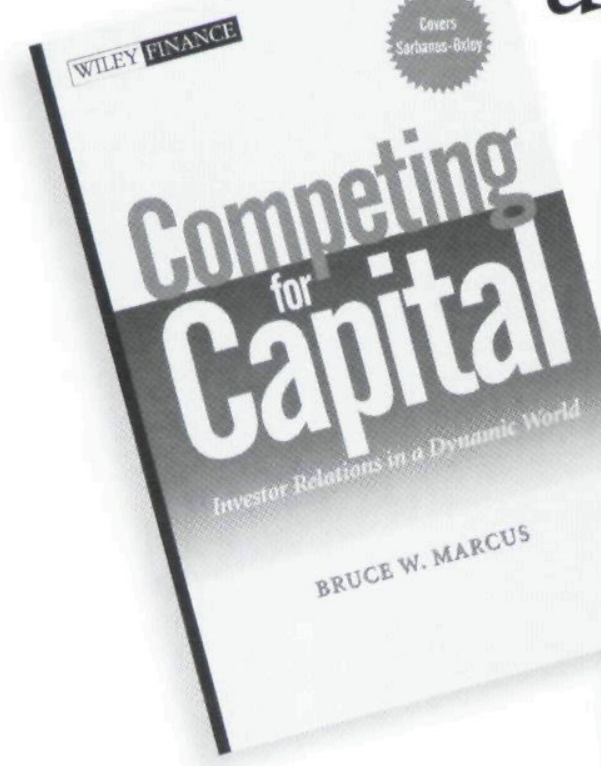

0-471-44862-1 • $240 \mathrm{pp} \cdot \bullet$ Cloth $\bullet \$ 79.95$

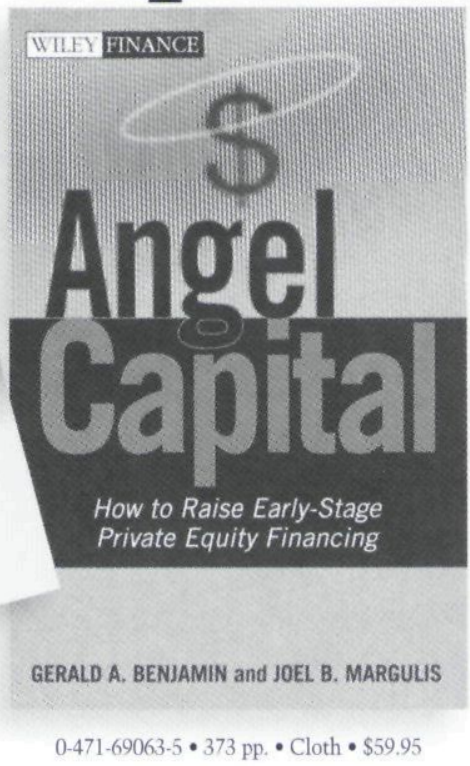

(W)WILE

Now you know.

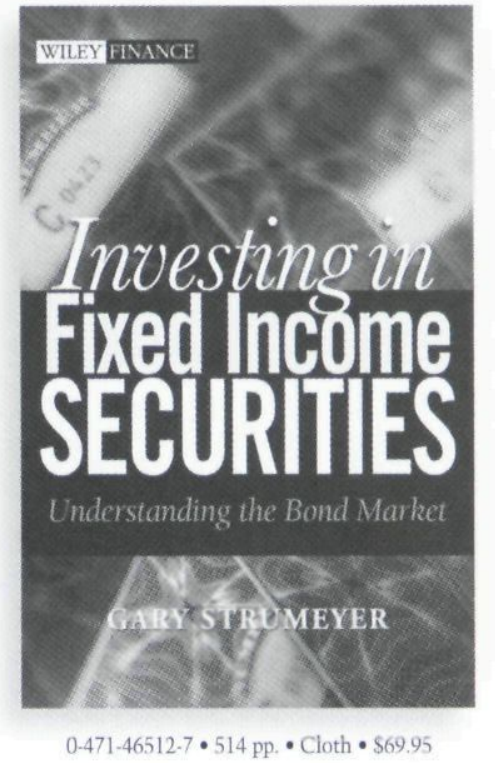


Copyright of Financial Analysts Journal is the property of CFA Institute. The copyright in an individual article may be maintained by the author in certain cases. Content may not be copied or emailed to multiple sites or posted to a listserv without the copyright holder's express written permission. However, users may print, download, or email articles for individual use. 